\section{The Dew Component of Strawberry Evapotranspiration}

\author{
D. Michael Glenn, C. Feldhake ${ }^{1}$, F. Takeda, and D.L. Peterson \\ U.S. Department of Agriculture, Agricultural Research Service, Appalachian \\ Fruit Research Station, 45 Wiltshire Road, Kearneysville, WV 25430
}

Additional index words. Fragaria $\times$ ananassa

\begin{abstract}
The objectives of this lysimeter study were to 1) evaluate the amount of dewfall, 2) determine the contribution of dew to daily evapotranspiration (ET) in fall-grown strawberries (Fragaria $\times$ ananassa Duch.), and 3) determine the relationship between actual and potential ET (PET) of strawberry. Dewfall amounts averaged $0.8 \mathrm{~mm} \cdot \mathrm{day}^{-1}$ and accounted for $33 \%$ of the daily ET during the 27 Sept. to 6 Nov. period. Daily ET was linearly related to PET calculated from the Penman-Monteith equation, with an accuracy of $\pm \mathbf{3} \mathbf{~ m m}$ based on lysimeter ET. Daily ET for 2- to 4-day periods was estimated with an accuracy of $\pm 1 \mathrm{~mm}$ using the Penman-Monteith. We conclude that dewfall cannot be ignored in the ET of fall-grown strawberries in the mid-Atlantic section of the United States.
\end{abstract}

Dew occurs when the temperature of objects declines to a temperature below the dewpoint of the surrounding air. This process is driven by radiational cooling that occurs following sunset. Nocturnal dewfall ranges from 0.01 to $5 \mathrm{~mm}$ (Wallin, 1967) and can provide up to $20 \%$ of the daily water consumption in some areas (Fritschen and Doraiswamy, 1973). The conditions necessary for heavy dewfall include clear skies, high relative humidity, and turbulent mixing near the soil surface (Monteith, 1957). These conditions are common in the fall season of the eastern United States.

There is little information on the contribution of dewfall in the water balance in the eastern United States (Wallin, 1967). Fritschen et al. (1977) and Gash and Stewart (1977) demonstrated that freestanding water on plant surfaces in coniferous forests contributes $25 \%$ to $40 \%$ of the seasonal evapotranspiration (ET). Freestanding water evaporates at a higher rate than transpiration (Stewart, 1977), and a Douglas fir [Pseudotsuga menziesii (Mirb.) Franco] forest had 20\% higher ET from a wetted canopy compared to a dry canopy (McNaughton and Black, 1973). Freestanding water on plant surfaces can be absorbed and contribute to the water economy of the plant (Stone, 1957), yet the primary value of dew is

Received for publication 13 Dec. 1995. Accepted for publication 18 June 1996. Mention of trademark, proprietary product, or vendor does not constitute a guarantee or warranty of the product by the U.S. Dept. of Agriculture and does not imply its approval to the exclusion of other products or vendors that also may be suitable. The cost of publishing this paper was defrayed in part by the payment of page charges. Under postal regulations, this paper therefore must be hereby marked advertisement solely to indicate this fact.

${ }^{1}$ U.S. Dept. of Agriculture-Agricultural Research Service Appalachian Soil and Water Research Station, Beckley, W.Va.

HortScience, Vol. 31(6), October 1996
The weight of the lysimeter was monitored with a load cell. The two lysimeters were located $25 \mathrm{~m}$ apart with one lysimeter planted strawberry. Both cultivars were planted in Sept. 1993 with $30 \mathrm{~cm}$ between plants and 60 to 'Allstar' and the other planted to 'Tribute' cm between rows. 'Allstar' is a spring-bearing strawberry and 'Tribute' is a day-neutral cultivar that produces fruit in spring and fall. 'Tribute' was fruiting and harvested weekly during the study. The initial ground cover estimate of 'Tribute' was $40 \%$, while 'Allstar' had $100 \%$ ground cover due to its vigorous stolons. Leaf area was estimated at the conclusion of the study by harvesting all leaves and stems from each cultivar and developing an allometric relationship between leaf and stem weight and leaf area from subsamples of the total biomass.

The following meteorological data were collected every $15 \mathrm{~min}$ from 23 Sept. to 6 Nov.: aspirated wet bulb and dry bulb temperature at canopy height at each lysimeter and at a 2-m height midway between each lysimeter; incident and reflected radiation 30 $\mathrm{cm}$ above the canopy at each lysimeter (model 3023 albedometer; Qualimetrics, Sacramento, Calif.); canopy temperature of 'Allstar' using an infrared sensor aimed down the row and positioned $10 \mathrm{~cm}$ above the canopy and inclined $\approx 20^{\circ}$ below horizontal (Carborundum Co., Solon, Ohio); precipitation with a Texas Sensors (Dallas) tipping bucket rain gauge at the 'Allstar' lysimeter; and wind speed (Met One; Campbell Scientific, Logan, Utah) $2 \mathrm{~m}$ above the canopy at each lysimeter. Data, including lysimeter weight, were collected by a CR7 datalogger (Campbell Scientific). Class A pan evaporation data and precipitation were collected Monday, Wednesday, and Friday of each week from a site $\approx 200 \mathrm{~m}$ from the lysimeters.

PET was calculated using the combination Penman-Monteith equation (Monteith, 1973). Net radiation was calculated as $70 \%$ of incident radiation. Actual lysimeter ET/ $\mathrm{m}^{2}$ was based on leaf area + exposed soil surface area of 0 and $3.87 \mathrm{~m}^{2}$ soil for 'Allstar' and 'Tribute', respectively.

Daily ET was calculated as the weight loss from sunrise to sunset. Sunrise and sunset were approximated by values of net radiation equal to $0 \mathrm{~W} \cdot \mathrm{m}^{-2}$. The actual times ET began and ceased were determined by examining each daily water use pattern and selecting the time and corresponding weight when the lysimeter weight was notably changing or stable in relation to sunrise or sunset. To compare lysimeter ET to pan evaporation, the lysimeter data were pooled over the 2- to 4-day intervals that pan evaporation data were collected $(\mathrm{n}=30)$.

The amount of dewfall was calculated as the increase in lysimeter weight following sunset when no precipitation was recorded. When precipitation occurred, dewfall could not be calculated. During the study, 23 days had measurable dew, 7 days had no measurable dew, and 15 days had measurable precipitation.

The load cell calibration was checked before and after the study with 90-kg weights in 20 - to $25-\mathrm{kg}$ increments. Lysimeter weight change during calibration was within $2 \%$ of actual weight change. An additional test of the calibration compared the lysimeter weight change during periods of precipitation to the amount of rain captured in the rain gauge at the 
class A pan site. Precipitation data were analyzed in a randomized complete-block design with three treatments: rain gauge and the two lysimeters. The 15 dates of precipitation were replications. There was no significant difference $(P \leq 0.01)$ between the average rain gauge precipitation and the two lysimeters (mean precipitation was $10 \mathrm{~mm}$ for all sensors). Analysis of variance of all other data was performed based on the presence or absence of dewfall. Each sampling date was a replication, and each lysimeter as a treatment in a randomized complete-block design.

\section{Results and Discussion}

Dewfall began to accumulate at or slightly before sunset in all dewfall events. Canopy temperature declined below air temperature at $2 \mathrm{~m}$ during these events (Fig. 1). Monteith (1957) observed that dewfall occurs at relative humidities of $91 \%$ to $99 \%$ when leaves are cooler than air and are at the dewpoint. The lysimeter with 'Allstar' accumulated about the same dewfall as the one with 'Tribute' despite a larger leaf area (11.7 vs. $5.7 \mathrm{~m}^{2}$, respectively) (Table 1). However, Sudmeyer et al. (1994) demonstrated that leaf area is a component of the dewfall mechanism and can increase the amount of dew captured. This difference suggests that in our climatic region, dewfall is often limited by the amount of water vapor and environmental conditions rather than surface area for condensation.

Dewfall accounted for $33 \%$ of daily ET during this study. Dew formation occurred on all but 7 of 30 days. Mean daily ET for the study period was $2.4 \mathrm{~mm}$ for 'Allstar' and 'Tribute', and there was not a significant difference in daily ET due to the cultivar (Table 1) measured for days with and without dewfall.

ET and ET-dew for dates with dewfall were similar to ET for dates without dew (Table 1).

Conditions for dew formation include clear and calm skies at night that are commonly followed by clear to partly cloudy skies and wind during the day. Clear and windy days favor high ET, whereas conditions of cloudy, calm winds suppress dew and ET. In contrast, evaporation from the class A pan and PET from the Penman-Monteith equation indicated no difference in PET for days with or without dewfall (Table 1). The lack of measurable differences attributable to climatic conditions associated with dew are the result, in part, of the low ET rates during the fall season.

Daily ET was linearly related to daily PET calculated from the Penman-Monteith equation (Fig. 2). The slope and intercept of the regression were not significantly different from 1 and 0 , respectively $(P \leq 0.05)$. The estimate of daily ET using the Penman-Monteith equation had an accuracy of $\pm 3 \mathrm{~mm} \cdot \mathrm{day}^{-1}$ based on the standard error of the differences between lysimeter ET and PET. When daily ET was estimated by the Penman-Monteith equation for 2- to 4-day periods, there was a linear relationship with slope and intercept not significantly different from 1 and 0 , respectively

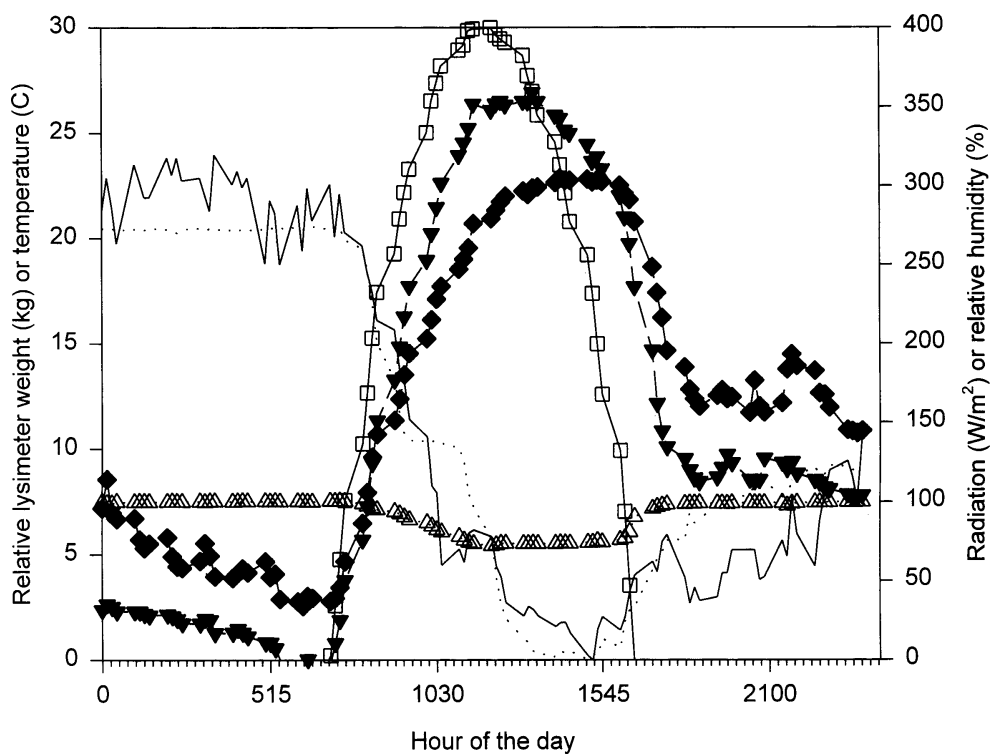

Fig. 1. Environmental measurements during a typical dew event. ( $\left.-{ }_{-}\right)$'Allstar'; $(\boldsymbol{\nabla})$ canopy temperature; $(\square)$ net radiation; $(\Delta)$ relative humidity; $(\ldots \ldots)$ 'Tribute'; $(\diamond)$ air temperature $2 \mathrm{~m}$.

Table 1. Relationship of dew and evapotranspiration (ET) in strawberry grown in lysimeters.

\begin{tabular}{|c|c|c|c|c|c|c|c|c|c|}
\hline \multirow[b]{3}{*}{ Cultivar } & \multirow{3}{*}{$\begin{array}{c}\text { Dewfall } \\
(\mathrm{mm})\end{array}$} & \multirow{3}{*}{$\begin{array}{c}\mathrm{ET}^{\mathrm{y}} \\
(\mathrm{mm})\end{array}$} & \multirow{3}{*}{$\begin{array}{c}\text { ET-dew } \\
(\mathrm{mm})\end{array}$} & \multicolumn{2}{|c|}{$\mathrm{PET}^{\mathrm{z}}$} & \multirow{2}{*}{\multicolumn{2}{|c|}{ ET/PET }} & \multirow{2}{*}{\multicolumn{2}{|c|}{ ET-dew/PET }} \\
\hline & & & & \multirow{2}{*}{$\begin{array}{l}\text { PAN }^{x} \\
(\mathrm{~mm})\end{array}$} & \multirow{2}{*}{$\begin{array}{l}\mathrm{P}-\mathrm{M}^{\mathrm{w}} \\
(\mathrm{mm})\end{array}$} & & & & \\
\hline & & & & & & PAN & P-M & PAN & P-M \\
\hline \multicolumn{10}{|c|}{ Days with dew } \\
\hline Allstar & 0.9 & 2.4 & 1.5 & & & 1.27 & 1.18 & 0.79 & 0.73 \\
\hline Tribute & 0.8 & 2.5 & 1.7 & & & 1.32 & 1.26 & 0.86 & 0.84 \\
\hline Mean $(n=24)$ & 0.8 & 2.4 & 1.6 & 2.0 & 2.1 & 1.29 & 1.22 & $0.82^{\mathrm{v}}$ & $0.79^{v}$ \\
\hline \multicolumn{10}{|c|}{ Days without dew } \\
\hline Allstar & 0 & 1.8 & 1.8 & & & 0.80 & 0.94 & 0.80 & 0.94 \\
\hline Tribute & 0 & 2.4 & 2.4 & & & 1.13 & 1.28 & 1.13 & 1.28 \\
\hline Mean $(n=7)$ & 0 & 2.1 & 2.1 & 2.3 & 2.1 & 0.97 & 1.11 & 0.97 & 1.11 \\
\hline
\end{tabular}

${ }^{\mathrm{z}} \mathrm{PET}=$ potential ET.

yET measured from lysimeter data.

xPET from a class A evaporation pan.

wET calculated from the Penman-Monteith equation.

'The presence or absence of dewfall was a significant factor $(P \leq 0.05)$. Cultivar had no significant effect.

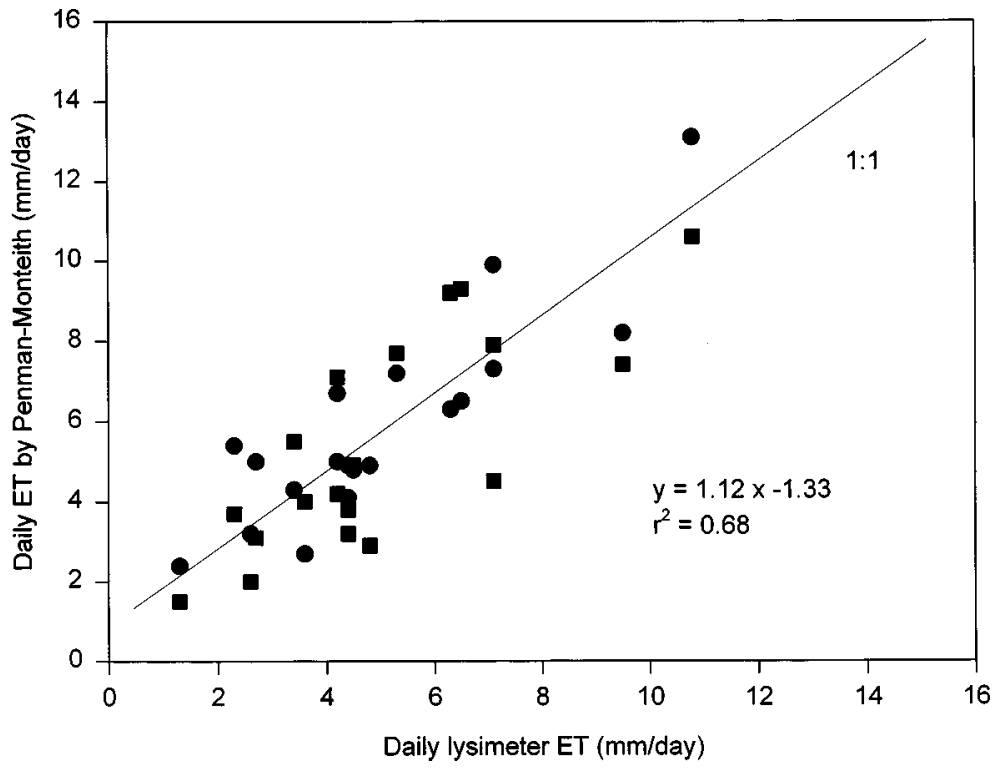

Fig. 2. Relationship between daily evapotranspiration (ET) in two lysimeters and ET predicted by the Penman-Monteith equation. (ם) 'Allstar'; (O) 'Tribute'. 

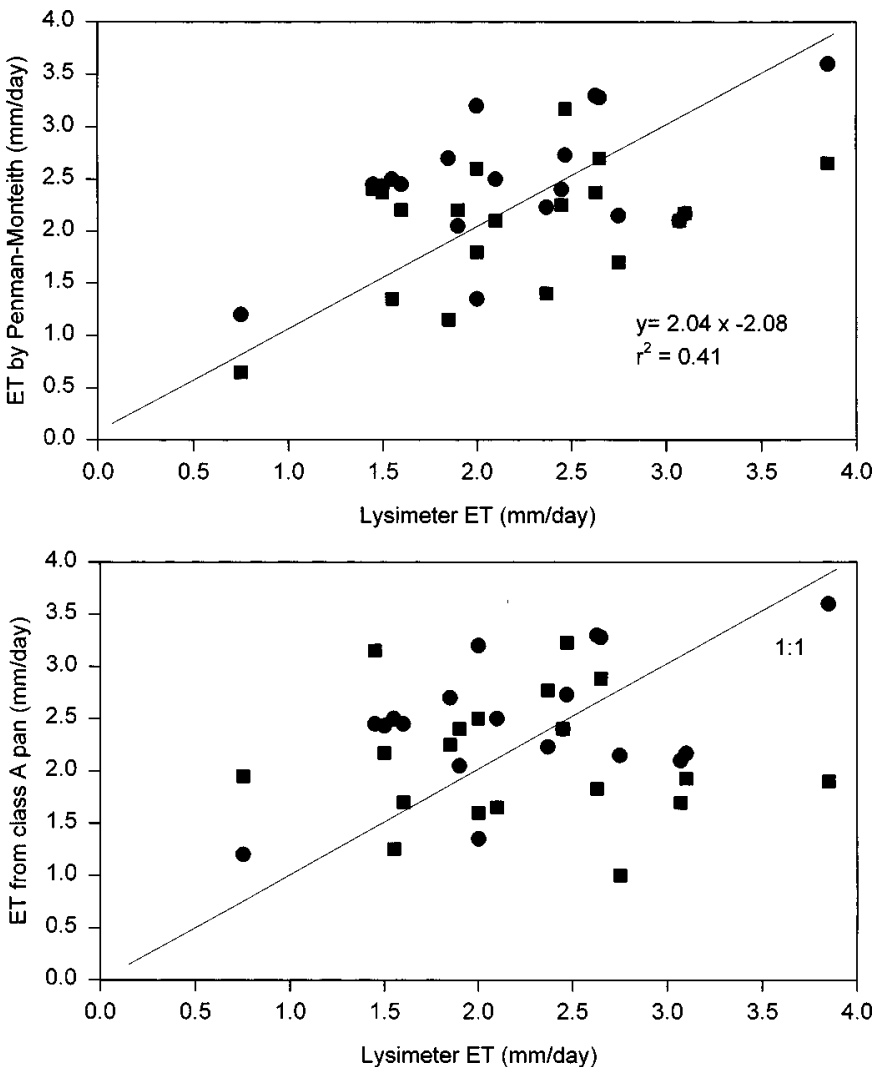

Fig. 3. Relationship between daily evapotranspiration (ET) in two lysimeters and ET predicted by the Penman-Monteith equation (upper) and class A pan (lower) for 2- to 4-day periods. The 1:1 line is presented for the nonsignificant relationships. (ם) 'Allstar'; (-) 'Tribute'.
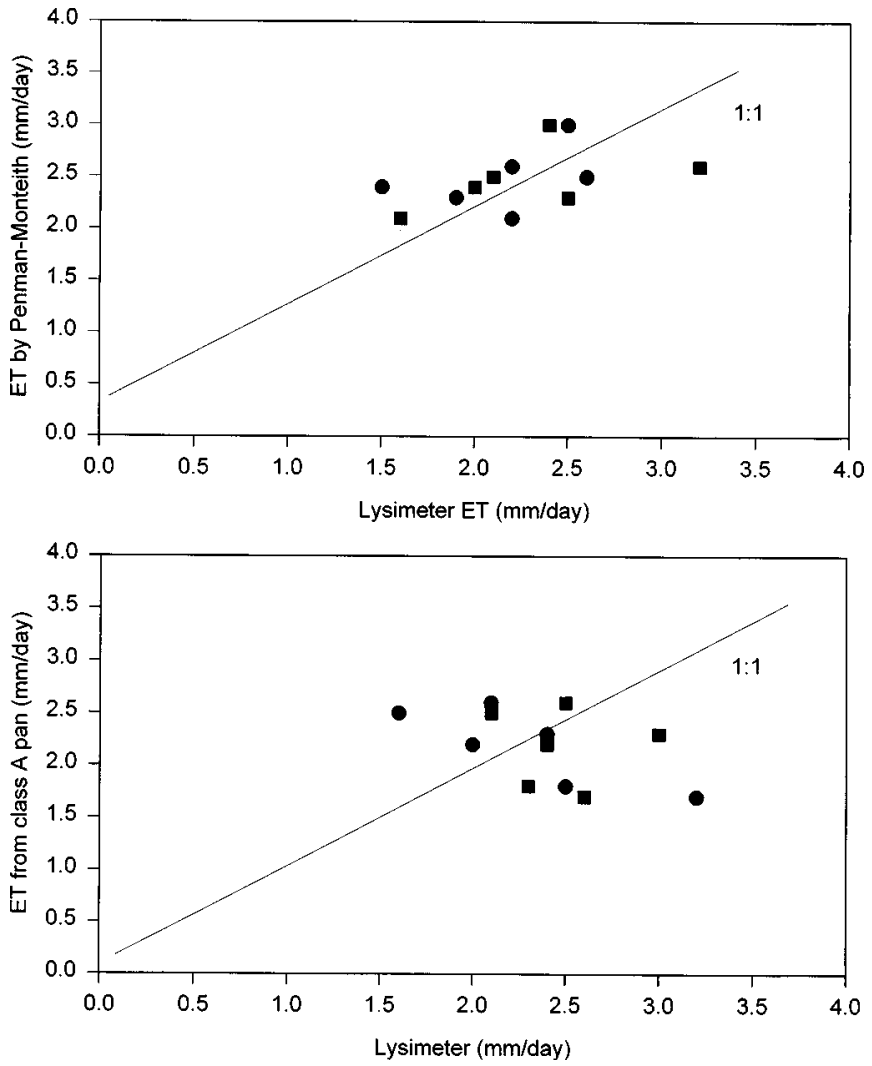

Fig. 4. Relationship between daily evapotranspiration (ET) in two lysimeters and ET predicted by the Penman-Monteith equation (upper) and class A pan (lower) for 7-day periods. The 1:1 line is presented for the nonsignificant relationships. ( $\square$ ) 'Allstar'; $(\mathbf{\bullet})$ 'Tribute'.
$(P \leq 0.05)$ (Fig. 3, top). This estimate of daily ET for 2- to 4-day periods had an accuracy of $\pm 1 \mathrm{~mm} \cdot \mathrm{day}^{-1}$. When daily ET was estimated from the class A pan for 2- to 4-day periods, there was no significant correlation $(P \leq 0.05)$ between lysimeter ET and PET calculated from the class A pan (Fig. 3, bottom). Daily estimates of ET using both the class A pan and the Penman-Monteith equation for 7-day periods demonstrated no significant linear relationship $(P \leq 0.05)$; however, the range of ET on a weekly basis was only 1.6 to $3 \mathrm{~mm} \cdot$ day ${ }^{1}$ in both (Fig. 4). The Penman-Monteith equation has been a reliable predictor of daily PET (Allen et al., 1989), whereas the class A evaporation pan is more suitable to weekly or monthly estimates of PET (Jensen, 1973) due to heat storage in the mass of water (Thom et al., 1981). These data confirm that the class A pan is inappropriate for estimating ET in the fall season for periods $<7$ days.

In the mid-Atlantic section of the United States, fall strawberry production is an expanding industry. Dew is typically considered a minor component of the water budget of plants, except in dew deserts of the world (Jones, 1983). Yet, we found that during fall, in this region, dew can account for about onethird of daily water use by strawberry, potentially reducing soil water depletion. Models have been developed for dew formation (Deshpande et al., 1995; Monteith, 1957; Sudmeyer et al., 1994; Wittich, 1995 and citations included therein). Simple methods are available for measuring dew formation (Wales-Smith, 1983) and for incorporating dewfall into irrigation scheduling criteria. Dew formation is common in the fall and relatively accurate daily ET rates can be estimated by summing PET and dewfall.

\section{Literature Cited}

Allen, R.G., M.E. Jensen, J.L. Wright, and R.D. Burman. 1989. Operational estimates of reference evapotranspiration. Agron. J. 81:650-662.

Deshpande, R.Y., K.G. Hubbard, D.P. Coyne, J.R. Steadman, and A.M. Parkhurst. 1995. Estimating leaf wetness in dry bean canopies as a prerequisite to evaluating white mold disease. Agron. J. 87:613-619.

Fritschen, L.J. and P. Doraiswamy. 1973. Dew: An addition to the hydrologic balance of Douglas fir. Water Res. 9:891-894.

Fritschen, L.J., J. Hsia, and P. Doraiswamy. 1977. Evapotranspiration of a Douglas fir determined with a weighing lysimeter. Water Resources Res. 13:145-148.

Gash, J.H.C. and J.B. Stewart. 1977. The evaporation from Theford Forest during 1975. J. Hydrol. 35:385-396.

Jensen, M.E. (ed.). 1973. Consumptive use of water and irrigation water requirements. Amer. Soc. Civil Eng., New York.

Jones, G.G. 1983. Plants and microclimate. Cambridge Univ. Press, New York.

McNaughton, K.G. and T.A. Black. 1973. A study of evapotranspiration from a Douglas fir forest using the energy balance approach. Water Resources Res. 9:1579-1590.

Monteith, J.L. 1957. Dew. Quart. J. Royal Meteorol. Soc. 83:322-341.

Monteith, J.L. 1973. Principles of environmental physics. Amer. Elsevier, New York. 


\section{Soll Management, Fertilization, \& Irrigation}

Rosenberg, N.J., B.L. Blad, and S.B. Verma. 1983. Microclimate-The biological environment. 2nd ed. Wiley, New York.

Stewart, J.B. 1977. Evaporation from the wet canopy of a pine forest. Water Resources Res. 13:915921.

Stone, E.C. 1957. Dew as an ecological factor. I. A review of the literature. Ecology 38:407-413.
Sudmeyer, R.A., R.A. Nulsen, and W.D. Scott. 1994. Measured dewfall and potential condensation on grazed pasture in the Collie River basin, southwestern Austral. J. Hydrol. 154:255269.

Thom, A.S., J.L. Thony, and M. Vauclin. 1981. On the proper employment of evaporation pans and atmometers in estimating potential transpira- tion. Quart. J. Royal Meteorol. Soc. 107:711736.

Wales-Smith, B.G. 1983. An inexpensive device for measuring net dewfall. Weather 38:54-56.

Wallin, J.R. 1967. Agrometeorological aspects of dew. Agr. Meteorol. 4:85-102.

Wittich, K.P. 1995. Some remarks on dew duration on top of an orchard. Agr. For. Meteorol. 72:167-180. 